\title{
DINAMIKA PRAKTEK TANGGUNGJAWAB SOSIAL BANK SYARIAH (Studi Bank Muamalat Makassar)
}

\author{
Muhammad Kamal Zubair \\ M. Ali Rusdi \\ Ismayanti \\ Institut Agama Islam Negeri (IAIN) Parepare \\ muhammadkamalzubair@iainpare.ac.id
}

\begin{abstract}
Abstrak
Artikel ini akan mengkaji bagaimana pelaksanaan tanggungjawab sosial bank Muamalat cabang Makassar dengan melihat fungsi sosial dari bank syariah yang sangat strategis dalam upaya mewujudkan kesejahteraan masyarakat. Tanggungjawab sosial perusahaan atau dikenal sebagai Corporate Social Responsibility telah menjadi trend baru yang menarik. Pelaksanaan CSR menjadi strategi bisnis bagi bank syariah meningkatkan citra bank syariah. Sebagai tanggungjawab sosial kepada masyarakat, Bank Muamalat cabang Makassar setiap tahun melaksanakan program community development secara berkelanjutan. Pelaksanaan CSR Bank Muamalat Cabang Makassar sudah sangat baik untuk lembaga keuangan syariah khususnya perbankan syariah. Hal ini terbukti dengan adanya kegiatan CSR dan juga dengan berjalannya programprogram yang berhubungan dengan sosial kemasyarakatan sehingga dapat mengurangi sedikit beban ekonomi masyarakat dengan memberikan santunan sosial keagamaan, dengan memberi bantuan pembangunan tempat ibadah, lembaga pendidikan sosial, panti asuhan yatim piatu. Dari kacamata nilai-nilai syariah, yaitu hubungan kepada Allah (hablumminallah), hubungan sesama manusia (habluminannas), dan hubungan dengan alam (hablum fil ardh), CSR yang dilaksanakan oleh Bank Muamalat Cabang Makassar memerhatikan ketiga aspek tersebut. Karena dalam setiap pelaksanaan kegiatannya, entitas tersebut selalu berkiblat pada visi dan misi-nya
\end{abstract}

Kata Kunci : Tanggungjawab Sosial, Perusahaan, Bank Syariah 


\section{Pendahuluan}

Kedudukan ekonomi dalam Islam sangatlah penting karena ekonomi merupakan salah satu faktor penting yang membawa pada kesejahteraan umat. Kegiatan-kegiatan ekonomi adalah pernyataan dari semangat ajaran Islam, karena ekonomi umat dan kemakmurannya adalah cita-cita yang ingin dicapai oleh umat Islam. ${ }^{1}$

Kegiatan perekonomian di Indonesia, terutama sektor keuangan sangat didukung oleh lembaga perbankan. Salah satu penggerak sektor keuangan tersebut adalah bank syariah. Bank syariah merupakan bank yang mempunyai peranan sama seperti bank umum lainnya, yaitu sebagai sektor pembiayaan sekaligus sebagai fungsi intermediasi. Secara umum tujuan utama bank syariah adalah mendorong dan mempercepat kemajuan ekonomi suatu masyarakat dan melakukan kegiatan perbankan, komersial dan investasi sesuai prinsip Islam. ${ }^{2}$

Dalam pandangan Chapra, selain memberikan jasa keuangan yang halal bagi komunitas muslim sebagai tujuan khusus, sistem keuangan dan perbankan Islam diharapkan juga memberikan kontribusi bagi tercapainya tujuan sosioekonomi Islam. ${ }^{3}$ Hal senada juga disampaikan oleh Antonio, dimana menurutnya bank syariah selain memiliki fungsi sebagai pengelola investasi dan penyedia jasa-jasa keuangan juga memiliki jasa sosial melalui qardhul hasan, zakat, atau dana sosial yang sesuai dengan ajaran Islam. ${ }^{4}$

\footnotetext{
${ }^{1}$ Isma'il Raji Al-Faruqi, Islamization of Knowledge: General Principles and Workplan, diterjemahkan Anas Mahyudin, Cet. 1, (Bandung: Pustaka, 1984), hal. 38

2 Veithzal Rivai, dkk., Bank and Financial Institution Management, (Jakarta : RajaGrafindo Persada, 2007), hal. 733

${ }^{3}$ M. Umer Chapra, Sistem Moneter Islam, (Jakarta: Gema Insani Press \& Tazkia Cendekia, 2000), hlm. 2

4 Muhammad Syafi'i Antonio, Bank Syariah dari Teori ke Praktik, (Jakarta: Gema Insani Press, 2001), hlm 201-202
} 
Dengan demikian jelas sekali bahwa fungsi sosial dari bank syariah sangat strategis dalam merealisasikan upaya mewujudkan kesejahteraan masyarakat melalui instrumen ekonomi Islam yang lain. Tetapi kemudian permasalahannya, sejauhmana pemenuhan tangungjawab sosial tersebut telah diwujudkan oleh bank syariah. Bank syariah harusnya memiliki dimensi spiritual yang lebih banyak dimensi spiritual ini tidak hanya menghendaki bisnis yang non riba, namun juga mampu memberikan kesejahteraan bagi masyarakat luas, terutama bagi golongan masyarakat ekonomi lemah.

Tanggungjawab sosial perusahaan atau apa yang dikenal sebagai Corporate Social Responsibility (selanjutnya disingkat CSR) telah menjadi trend baru yang menarik. Bahkan CSR merupakan isu yang hangat di Indonesia. Berbagai organisasi di Indonesia mulai menerapkan CSR dalam kegiatan bisnisnya, begitu pula pada industri perbankan. Walaupun industri perbankan tidak memiliki dampak langsung terhadap sumber daya alam, namun beberapa perbankan cukup aktif dalam melaksanakan kegiatan CSR. Posisi bank syariah sebagai lembaga keuangan yang sudah eksis ditingkat nasional maupun internasional harus menjaadi lembaga keuangan percontohan dalam menggerakkan program CSR.

Pelaksanaan CSR pada industri perbankan sejauh ini baru sebatas pada tindakan filantrofis dan belum terintegrasi dengan nature bisnis dari industri perbankan yang terkait aktivitas perolehan dan penyaluran dana. ${ }^{5}$ Bila kita cermati informasi tentang realisasi program CSR sektor perbankan dalam advertorial/korporatorial atau laporan tahunan di berbagai media termasuk

5 Dede Abdul Hasyir, Praktek Corporate Social Responsibility Yang Terintegrasi Dan Contoh Implementasinya Pada Industri Perbankan, Working Paper Research Days, Faculty of Economics - Padjadjaran University, Bandung Oktober 2009 
website sejumlah bank nasional maupun asing, didapati kecenderungan kesamaan pilihan bidang program. Bidang-bidang yang dimaksud adalah: 1) pendidikan (beasiswa, renovasi sekolah, bantuan buku); 2) kesehatan (pengobatan massal, renovasi gedung puskesmas); 3) ekonomi (bantuan modal, kegiatan ekonomi produktif, mediasi ke akses permodalan); 4) bidang sosialkeagamaan (pembangunan sarana ibadah, khitanan massal); 5) bantuan bencana (bantuan obat dan makanan, upaya evakuasi hingga pembangunan kembali rumah dan infrastruktur yang rusak). Boleh dibilang kelima bidang ini seperti menjadi format standar dari realisasi program CSR sektor perbankan. ${ }^{6}$

Aktivitas CSR perbankan syariah diselenggarakan sesuai dengan Undangundang No 21 Tahun 2008 yang menyatakan bahwa bank syariah dapat melakukan kegiatan yang bersifat bisnis, sosial yang bisa disalurkan kembali kepada orang yang berhak untuk menerimanya. Misalnya, pada tahun 2012 lalu, Perbankan Syariah di Indonesia bersinergi mencanangkan Islamic Banking Corporate Social Responsibility (IB-CSR) dengan total pembiayaan senilai Rp 1,450 miliar. IB CSR ini menyalurkan dananya kepada yang berhak dengan komposisi 50\% untuk pengusaha ekonomi mikro lewat dana bergulir, 25\% untuk sektor pendidikan, dan 25\% untuk bantuan bencana alam. Dari dana tersebut disisihkan 2,5\% untuk dana promosi. ${ }^{7}$

Sebagai tanggungjawab sosial kepada masyarakat, Bank Muamalat Indonesia setiap tahun melaksanakan program community development secara berkelanjutan. Peran dan tanggung jawab sosial perusahaan merupakan bagian yang tidak terpisahkan dari tujuan usaha Bank Muamalat untuk mewujudkan

${ }^{6}$ http/www.csrIndonesia.com

${ }^{7}$ http/www.bi.go.id. 
tatanan masyarakat yang adil dan makmur sejalan dengan prinsip-prinsip dasar ekonomi syariah. Program community development yang dilaksanakan berupa KUM3 (Komunitas Usaha Mikro Muamalat berbasis Masjid) yang bertujuan untuk menumbuhkan ekonomi keluarga miskin di Indonesia, dan masjid sebagai basis pembinaannya. Program KUM3 diarahkan kepada pembinaan serta dukungan yang diberikan dalam rangka memberdayakan usaha mikro dan pengusaha kecil berupa dana bergulir dan bantuan biaya operasional program. Adapun penyaluran dana bergulir dan bantuan biaya operasional program untuk KUM3 tersebut sejak tahun 2008 s/d 2012 masing-masing berjumlah sebesar Rp. 6,46 milyar dan sebesar Rp. 2,6 milyar, yang diperuntukan bagi 4.697 orang miskin. Seluruh dana sosial tersebut bersumber dari Zakat, Infaq dan Shodaqoh (ZIS) BMI. ${ }^{8}$ Kegiatan ini telah menjangkau 22 Propinsi di Indonesia, salah satunya adalah Propinsi Sulawesi Selatan dengan jumlah masjid yang bergabung sebanyak 202 masjid.

Program ini terus tumbuh dan mendapat kepercayaan dari masyarakat karena mampu menumbuhkan komunitas usaha mikro yang taat kepada azasazas ekonomi syariah. Namun demikian, untuk mengukur keberhasilan program tanggungjawab sosial tersebut berdasarkan manfaatnya bagi masyarakat, perlu penelitian lebih lanjut. Oleh karena itu penelitian ini akan mereview bagaimana pelaksanaan tanggungjawab sosial salah satu bank syariah di Indonesia, yaitu Bank Muamalat yang ada di Makassar, Sulawesi Selatan.

${ }^{8}$ Laporan Pelaksanaan Tata Kelola Perusahaan Tahun 2010 Bank Muamalat Indonesia 


\section{Corporate Social Responsibility (CSR) dalam Tinjauan Islam}

Konsep yang digagas Howard Rothmann Browen tentang Corporate Social Responsibility (CSR) pertama kali muncul dalam tulisan Social Responsibility of the Businessman tahun 1953. Istilah tanggungjawab sosial perusahaan bukanlah sesuatu yang baru dalam beberapa literature. Belakangan CSR banyak diadopsi karena dapat menjadi penawar kesan buruk perusahaan yang terlanjur dalam pikiran masyarakat dan lebih dari itu pengusaha dianggap sebagai pemburu uang yang tidak peduli pada dampak kemiskinan dan kerusakan lingkungan. CSR menjadi topik yang sering dibicarakan dan didiskusikan oleh dunia usaha dan juga kalangan akademisi.

CSR dalam perspektif Islam merupakan konsekuensi inhern dari ajaran Islam itu sendiri. Tujuan dari syariat Islam (maqashid asy-syariah) adalah maslahah sehingga bisnis adalah upaya untuk menciptakan maslahah, bukan sekedar mencari keuntungan. Aktifitas CSR pada dasarnya juga melekat secara inhern pada bank syariah sebagai konsekuensi kebersandaran bank syariah pada ajaran Islam. ${ }^{9}$

Berbeda dengan bank konvensional, bank syariah tidak dapat memisahkan secara dikotomis antara orientasi bisnisnya dengan orientasi sosialnya. Orientasi bisnis seharusnya juga membawa orientasi sosial, atau setidaknya tidak kontradiksi dengan orientasi sosial. Hal ini membawa konsekuensi pada kuatnya karakter sosial dari perbankan syariah, relatif jika dibandingkan dengan bank konvensional. Sebenarnya, dalam pandangan Islam kewajiban melaksanakan CSR bukan hanya menyangkut pemenuhan

\footnotetext{
${ }^{9}$ Rusdi, M. A. (2017). Maslahat Sebagai Metode Ijtihad Dan Tujuan Utama Hukum
} Islam. DIKTUM: Jurnal Syariah dan Hukum, 15(2), 151-168. 
kewajiban secara hukum dan moral, tetapi juga strategi agar perusahaan dan masyarakat tetap survive dalam jangka panjang. Jika CSR tidak dilaksanakan maka akan terdapat lebih banyak biaya yang harus ditanggung perusahaan. Sebaliknya jika perusahaan melaksanakan CSR dengan baik dan aktif bekerja keras mengimbangi hak-hak dari semua stakeholders berdasarkan kewajaran, martabat dan keadilan, dan memastikan distribusi kekayaan yang adil, akan benar-benar bermanfaat bagi perusahaan dalam jangka panjang.

Program CSR kebanyakan dilakukan dalam bentuk community development yang cenderung bersifat karitatif, responsif, berorientasi jangka pend ek, dan kurang melibatkan masyarakat. Program CSR seringkali hanya sebagai program peredam gejolak, yang nampak ketika terjadi kasus keributan di dalam masyarakat. Salah satu penyebab lemahnya pelaksanaan CSR kemungkinan adalah karena masih adanya anggapan bahwa CSR adalah sentra biaya (cost center) sehingga akan mengurangi laba perusahaan. Kompetisi perbankan syariah yang ketat dan orientasi maksimasi keuntungan juga seringkali menyebabkan kecenderungan bank syariah untuk lebih melayani kelompok kuat dan profitable. Karenanya, fungsi sosial bank syariah dalam memfasilitasi keterkaitan antara voluntary sector dengan pemberdayaan ekonomi marjinal belum optimal.

Corporate Social Resposibility dalam Islam bukanlah sesuatu yang baru, tanggung jawab sosial sangat sering disebutkan dalam al Qur'an. Salah satu diantaranya dijelaskan dalam Surah Al-Baqarah 205 :

Terjemahan : 
"Dan apabila ia berpaling (dari kamu), ia berjalan di bumi untuk mengadakan kerusakan padanya, dan merusak tanam-tanaman dan binatang ternak, dan Allah tidak menyukai kebinasaan".

Ayat di atas menggambarkan secara nyata bagaimana Islam sangat memperhatikan kelesatarian alam. Segala usaha dalam bentuk bisnis maupun nonbisnis harus mampu melestarikan alam sebagai bentuk pertangungjawaban sosial. CSR pada dasarnya merupakan konsep berbagi atau saling membantu antara manusia dengan harta atau profit oleh suatu perusahaan. Implementasi CSR sudah diterapkan sejak kekhalifaan Rasulullah, selama masa hidup Rasululllah selalu menyediakan bantuan keuangan kepada fakir miskin dari Baitul Maal.

Rasulullah juga menularkan sifatnya tersebut kepada para sahabatsahabat beliau, ada yang menciptakan lapangan pekerjaan, bahkan Rasulullah sampai membayarkan utang-utang orang miskin yang tidak mampu melunasi utangnya. Dalam prespektif Islam, CSR termasuk dalam etika bisnis dimana Islam menganjurkan ketika melakukan bisnis haruslah diikuti dengan tanggungjawab sosial kepada orang lain, agar bisnis yang dijalankan tidak merugikan orang-orang sekitar. Terdapat beberapa prinsip yang sebetulnya menggambarkan adanya hubungan antara manusia dan penciptanya, yaitu Allah SWT. Prinsip-prinsip ini adalah berbagi dengan adil, rahmatan lil alamin (rahmat bagi seluruh alam), dan maslahah (kepentingan masyarakat). Hal tersebut berkaitan erat dengan tujuan ekonomi syariah, yaitu mengedepankan kepentingan masyarakat.

CSR dalam prespektif Islam berasal dari prinsip-prinsip inti dalam Al Qur'an. Ada tiga prinsip utama dalam Al Qur'an yang menjadi dasar dalam CSR, yaitu: (1) Kekhalifaan manusia dimuka bumi; (2) Akuntabilitas Ilahi dan (3) 
Kewajiban manusia untuk mencegah kejahatan dan memerintahkan kebaikan. ${ }^{10}$ Prisip kekhalifaan manusia menjelaskan bahwa manusia adalah wakil Allah dimuka bumi, sehingga segala isi bumi ini adalah kepemilikan Allah manusia hanya dititip sebagai penjaga amanah. Prinsip akuntanbilitas ilahi merupakan implikasi dari prinsip kekhalifaan manusia dimana manusia sebagai wakil Allah di bumi, sehingga manusia diwajibkan bertanggungjawab atas segala yang diamanahkan Allah kepada manusia. Kemudian untuk prinsip ketiga manusia memiliki kewajiban untuk mencegah kejahatan dan memerintahkan kepada kebaikan dikarenakan manusia sebagai wakil Allah yang harus mempertanggungjawabkan seluruh amanah ini.

Penjelasan di atas menunjukkan bahwa dalam Islam banyak dijelaskan mengenai CSR itu sendiri, dimana manusia sebagai khalifatul fil ardh dan abd Allah, sehingga manusia memiliki tanggungjawab kepada Allah sebagai pemilik tertinggi dan manusia juga bertanggungjawab kepada sesama makhluk (manusia, hewan dan alam sekitar). ${ }^{11}$ Begitu pula dengan konsep untuk korporasi sendiri, konsep pertangungjawabannya tidak hanya terkhusus pada stockholder dan stakeholder saja melainkan, ada aspek yang lebih luas dalam stakeholder yang terbagi menjadi direct stakeholder dan indrect stakeholder.

\section{Pelaksanaan Tanggungjawab Sosial Bank Muamalat Cabang Makassar}

Lembaga keuangan syariah khususnya perbankan syariah pada umumnya dapat melakukan Corporate Social Responbility (CSR) dalam bentuk tindakan

10 Syad Farrok, On Corporate Social Responsibility of Islamic Financial Instittusions. Islamic Economic Studies 15, no. 1, July 2007, h. 21

11 Iwan Triyonwono, Sinergi Oposisi Biner: Formulasi Tujuan Dasar Laporan Keuangan Syariah. IQTISAD Journal of Islamic Economics 4, No. 1. Maret 2003, h. 15 
filantrofis atau melalui pendirian yayasan CSR. Bank Syariah sudah seharusnya melakukan kegiatan CSR seperti yang tercantum pada UU No.40/2007 sebagai bagian dari kegiatan bisnis utamanya yang berarti dilaksanakan sebaik-baiknya dengan tujuan sustainability bank syariah, lingkungan dan komunitas di sekitarnya.

Integrasi CSR dengan bisnis inti perbankan dapat diwujudkan dengan penyaluran dana yang menyertakan pertimbangan potensi kemaslahatan sosial dan lingkungan di masa depan. The equator principles merupakan prinsip pendanaan dan manajemen risiko proyek yang mendorong kemakmuran ekonomi, perlindungan lingkungan hidup, dan keadilan sosial. Prinsip-prinsip ini terutama diterapkan pada jenis pendanaan proyek-proyek yang besar, kompleks, dan mahal seperti penghasil daya, pertambangan, infrastruktur transportasi, dan pengelolaan wilayah CSR adalah komitmen perseroan untuk berperan serta dalam pembangunan ekonomi berkelanjutan guna meningkatkan kualitas kehidupan dan lingkungan yang bermanfaat, baik bagi perseroan sendiri, komunitas setempat, maupun masyarakat pada umumnya.

Pelaksanaan CSR pada Bank Muamalat terbagi dalam dua bentuk kegiatan, yaitu kegiatan eksternal dan kegiatan internal. Kegiatan eksternal yaitu kegiatan CSR yang diadakan oleh cabang pembantu dan kantor kas dengan melibatkan mitra sebagai pelaksana di lapangan. Misalnya bekerjasama dengan Baznas, Dompet Dhuafa, Rumah Zakat, Bamuis, dll. Sedangkan kegiatan internal yaitu kegiatan CSR yang diselenggarakan oleh internal cabang Makassar sendiri tanpa melibatkan mitra. Misalnya kegiatan bakti sosial dan lain-lain. Titik tumpu dari pelaksanaan ini ada di Kantor Cabang, dimana setiap kantor cabang memiliki sebuah daerah binaan. Dari beragam kegiatan eksternal, masing- 
masing cabang mengutamakan program yang telah ditetapkan oleh Direksi dan Komite CSR. Diluar dari program yang telah ditetapkan, dapat dilaksanakan dengan berpedoman kepada tema program CSR dan menyesuaikan dengan ketersediaan anggaran yang telah dialokasikan untuk CSR.

Bank Muamalat cabang Makassar secara berkelanjutan dan sistematis menerapkan program CSR untuk mewujudkan salah satu misi perseroan yang terkait dengan usaha menciptakan suatu kondisi yang ramah lingkungan terhadap masyarakat sekitarnya. Kegiatan tersebut meliputi kegiatan-kegiatan yang terkait Program Kemitraan dan Bina Lingkungan.

Berdasarkan data yang diperoleh peneliti dari informan di Bank Muamalat cabang Makassar yaitu terkait program tanggungjawab sosial yang dilaksanakan Bank Muamalat cabang Makassar bahwa program tersebut sudah dilaksanakan dalam beberapa tahun terakhir yaitu pada tahun 2015 , 2016, dan 2017, sesuai penuturan informan:

"Bank Muamalat sendiri telah melaksanakan program CSR pada tahun 2015, 2016, dan 2017. Kegiatan-kegiatan CSR yang dilaksanakan ada beberapa setiap tahunnya."12

Salah satu bentuk pelaksanaan CSR pada Bank Muamalat cabang Makassar adalah pada bidang pendidikan disertai dengan optimalisasi dibidang lain seperti kesehatan, pemberdayaan ekonomi, sosial kemasyarakatan dan bencana alam. Program-program CSR tersebut dilaksanakan secara berkesinambungan oleh Bank Muamalat. Berdasarkan data yang telah diperoleh dari Bank Muamalat dari kegiatan CSR yang dilaksanakan pada tahun 2016,

12 Wawancara dengan Hulyani Yusuf, Pimpinan Bank Muamalat Cabang Makassar Tgl. 17 Oktober 2018 
pelaksanaan CSR di Bank Muamalat bekerja sama dengan mitra, baik pemerintah maupun non pemerintah yang berskala nasional dan dapat dipercaya. Bank Muamalat sebagai pemilik program, namun pelaksanaan di lapangan dilakukan bersama mitra untuk menjalankan, memonitor dan mengevaluasi program. Beberapa contoh mitra yaitu, UPZ Bank Muamalat, Baznas, BAMUIS Bank Muamalat, Rumah Zakat, Dompet Dhuafa, dll. Melalui program-program CSR tersebut, masyarakat dapat merasakan manfaat dari kehadiran Bank Muamalat dengan komitmen manajemennya yang terkait peningkatan kesejahteraan dan taraf hidup masyarakat di sekitarnya. Termasuk pemeliharaan lingkungan sekitar melalui pemanfaatan program-program CSR.

Pelaksanaan CSR pada PT Bank Bank Muamalat cabang Makassar belum pesat seperti pelaksanaan CSR pada bank-bank konvensional. Hal tersebut dipengaruhi oleh omset (profit) perusahaan, kurangnya omset pada Bank Muamalat menyebabkan kurangnya kegiatan CSR yang dilaksanakan setiap tahunnya. Hal tersebut seperti yang diungkap oleh informan dari Bank Muamalat yaitu:

"Pelaksanaan CSR Bank Muamalat cabang Makassar masih kegiatan yang dalam skala kecil bila dibandingkan dengan bank-bank konvensional yang melaksanakan banyak kegiatan CSR". ${ }^{13}$

Dari pendapat tersebut terlihat bahwa salah satu faktor yang menyebabkan sedikitnya kegiatan CSR yang dilaksanakan oleh Bank Muamalat cabang Makassar yaitu disebabkan oleh omset perusahaan Bank Muamalat belum memiliki omset yang besar seperti bank-bank konvensional yang omsetnya sudah mampu melaksanakan kegiatan CSR berskala lebih besar dari

13 Wawancara dengan Bapak Anhar Romansyah P, Pimpinan Bank Muamalat KCP Pettarani, tgl. 24 Oktober 2018 
Bank Muamalat. Faktor lain yang menjadi penyebab tidak optimalnya pelaksanaan CSR di Bank Muamalat sesuai yang dikatakan oleh salah satu pimpinan dari Bank Muamalat, yaitu:

"Hal ini disebabkan karena program yang dilaksanakan di Bank Muamalat cabang Makassar dirancang oleh pusat dan pusat juga yang memberikan dana masing-masing terhadap cabang sesuai dengan kebutuhan dana CSR masing-masing cabang."14

Pernyataan tersebut menunjukkan bahwa kegiatan CSR yang dilaksanakan masih dikelola langsung oleh pusat sehingga setiap cabang hanya fokus pada kegiatan bisnis. Kantor cabang tidak diberikan kewenangan untuk merancang kegiatan CSR sendiri. Kegiatan CSR yang dilaksanakan oleh cabang atau dikelola langsung oleh cabang akan berdampak negatif pada profit perusahaan sehingga menjadi alasan mengapa pusat yang mengelola langsung kegiatan. Penjelasan informan terkait penyebab lainnya, yaitu:

"Bank Muamalat cabang tidak diberikan wewenang secara khusus untuk mengurus kegiatan CSR karena cabang diberikan tanggungjawab atau beban untuk menjalankan kegiatan bisnis. Ketika cabang diberikan wewenang secara khusus untuk merancang kegiatan CSR sendiri, maka akan mengganggu fokus utama mereka yaitu menjalankan kegiatan bisnis dengan maksimal dan tidak dapat dipungkiri bahwa Bank Muamalat merupakan entitas yang berorientasi pada pencapaian laba, sehingga karyawan lebih difokuskan terhadap kegiatan bisnis demi pencapaian target perbankan."15

Menurut informasi yang didapatkan ada beberapa faktor lain yang menyebabkan mengapa pelaksanaan kegiatan CSR di Bank Muamalat cabang

\footnotetext{
14 Wawancara dengan Hulyani Yusuf, Pimpinan Bank Muamalat Cabang Makassar Tgl. 17 Oktober 2018

15 Wawancara dengan A. Gessa Magfirah, Pimpinan Bank Muamalat Kantor Kas Pengayoman, tgl. 22 Oktober 2018
} 
Makassar tidak seoptimal perbankan konvensional lainnya selain faktor kegiatan bisnis yang menjadi fokus setiap cabang pada Bank Muamalat. Menurut penjelasan informan, yaitu:

"Kurangnya SDM yang bertanggung jawab khusus pada divisi CSR, mengakibatkan pelaksanaan CSR tidak optimal di cabang. Kurangnya inisiatif perorangan karena disebabkan mereka tidak memiliki waktu yang cukup untuk memikirkan hal tersebut karena terlalu sibuk dengan pekerjaan masing-masing."16

Sumber daya manusia di Bank Muamalat cabang Makassar menjadi salah satu faktor atau penyebab utama mengapa pelaksanaan CSR tidak optimal. Kurangnya SDM yang fokus pada divisi khusus yang menangani kegiatan CSR dan para karyawan lain juga memiliki tanggung jawab masing-masing yang memiliki deadline sehingga inisiatif mereka kurang untuk mengerjakan pekerjaan diluar tanggungjawabnya. Disamping itu terdapat kendala-kendala seperti yang disampaikan informan:

"Kendalanya juga karena cabang tidak ada bagian yang khusus menangani masalah CSR. Cabang tidak dibebankan mengurusi CSR secara khusus karena cabang difokuskan untuk menjalankan kegiatan bisnis perusahaan, sehingga untuk kegiatan CSR dikelola langsung oleh pusat". ${ }^{17}$

Pelaksanaan program CSR Bank Muamalat, sebelumnya dikelola dan disalurkan oleh manajemen Bank Muamalat sendiri namun dengan pertimbangan agar lebih fokus dalam menjalankan kegiatannya untuk memberikan hasil yang lebih baik dan manfaat yang maksimal serta

\footnotetext{
16 Wawancara dengan Hulyani Yusuf, Pimpinan Bank Muamalat Cabang Makassar Tgl. 17 Oktober 2018

17 Wawancara dengan Darmawangsah, Karyawan Bank Muamalat Cabang Makassar Tgl. 19 Oktober 2018
} 
pelaksanaan yang lebih profesional, pengelolaan CSR Bank Muamalat kemudian dikelola melalui lembaga yang disebut dengan Baitulmaal Muamalat (BMM). ${ }^{18}$

Program CSR yang dilakukan Bank Muamalat Cabang Makassar adalah pemberian santunan dengan memberikan santunan sosial keagamaan, berupa bantuan pembangunan tempat ibadah, lembaga pendidikan sosial, panti asuhan yatim piatu di Kota Makassar dan program berbagi cahaya ramadhan dengan memberikan makanan untuk acara sahur, berbuka dan lebaran (SBL) kepada keluarga dhuafa di Kota Makassar. Sebagaimana disampaikan informan :

“Bentuk CSR yang dilaksanakan Bank Muamalat Cabang Makassar berupa hibah dengan memberikan santunan kepada pihak yang dianggap layak. Kegiatan-kegiatan secara rutin dilaksanakan pada bulan ramadhan." 19

Tujuan dari program CSR yang dilaksanakan oleh Bank Muamalat Cabang Makassar adalah dalam rangka meningkatkan pengetahuan masyarakat akan keberadaan Bank Muamalat terutama di kota Makassar karena sangat penting untuk memperkenalkan keberadaan Bank Muamalat Cabang Makassar sebagai salah satu upaya perusahaan mengembangkan pengaruh yang positif di tengahtengah masyarakat dan untuk meningkatkan kualitas masyarakat di sekitar perusahaan mulai dari kualitas perekonomian sampai kualitas sosial masyarakat.

Menurut penulis, tujuan dari pelaksanaan program CSR oleh Bank Muamalat Cabang Makassar dapat digolongkan dalam CSR yang bertujuan Suistainability Perusahaan Jangka Panjang dan juga CSR Murni Sosial, karena dalam pelaksanaan program CSR Bank Muamalat Cabang Makassar secara

\footnotetext{
18 Laporan Tahunan, Annual Report 2015 PT. Bank Muamalat Indonesia

19 Wawancara dengan Anugerah Rahmi selaku Legal Officer Bank Muamalat cabang Makassar tanggal 22 Oktober 2018 
konsisten memberikan santunan kepada pihak yang tidak terkait dengan perusahaan dan memanfaatkan untuk menarik perhatian calon nasabah baru. Dengan melaksanakan CSR secara konsisten dalam jangka panjang, maka akan menumbuhkan rasa penerimaan masyarakat terhadap kehadiran perusahaan. Kondisi seperti itulah yang pada gilirannya dapat memberikan keuntungan kepada perusahaan. Investasi jangka panjang ini diyakini oleh perusahaan bahwa ada korelasi positif antara pelaksanaan CSR dengan meningkatnya apresiasi dunia internasional maupun domestik terhadap perusahaan bersangkutan. ${ }^{20}$

Bank Muamalat Cabang Makassar tidak membentuk tim secara khusus karena perusahaan melibatkan seluruh karyawan yang ada untuk mensukseskan kegiatan. Namun dalam tahap perencanaan ini ditunjuk penanggungjawab yang bertugas menyiapkan kegiatan yang sesuai dengan tujuan dan target perusahaan. Proses perencanaan bermula dari analisis secara akurat baik terhadap lingkungan internal maupun eksternal perusahaan. Hasil analisis kemudian ditindaklanjuti dengan identifikasi dan klasifikasi secara jelas, spesifik, dan menyeluruh dari tiap risiko yang ada.

Dalam UU Nomor 25 Tahun 2007 tentang Penanaman Modal mengamanahkan, bahwa:

"Setiap Penanam modal berkewajiban melaksanakan tanggung jawab sosial perusahaan" (Pasal 15b), serta memenuhi ketentuan Good Corporate Governance (GCG) terkait kewajiban penyaluran dana sosial perusahaan."

20 Khairunisa, Analisa Perbandingan Rasio Keuangan Bank Syariah Sebelum dan Sesudah Menerapkan Corporate Social Responsibility (CSR) Studi Kasus PT Bank Muamalat Tbk. Skripsi. Jakarta : Fakultas Syariah dan Hukum UIN Syarifhidayatullah, 2010 
Bank Muamalat Indonesia telah mengalokasikan dana CSR sebesar 2,5 \% dari laba perusahaan. Penyaluran dana dilakukan melalui Baitulmaal Muamalat (BMM), Yayasan dana Dakwah Pembangunan (YDDP) Majelis Ulama Indonesia (MUI) dan Ikatan Cendikiawan Muslim se-Indonesia (ICMI). ${ }^{21}$ Ini merupakan wujud dari komitmen Bank Muamalat untuk ikut andil dalam memajukan ekonomi masyarakat melalui usaha mikro dengan prinsip syariah.

Kemandirian juga menjadi pegangan Bank Muamalat cabang Makassar dalam melaksanakan program CSR, di mana dalam melaksanakan kegiatan amal Bank Muamalat cabang Makassar melaksanakan sendiri dengan lebih melibatkan seluruh pihak yang ada dalam perusahaan sehingga bersifat sentralistik dengan meminimalisir keterlibatan dari pihak lain seperti pemerintah setempat, institusi pendidikan dan lainnya. Hal ini dilakukan salah satunya adalah untuk meminimalisir pengeluaran dalam melaksanakan kegiatan sehingga dana yang digunakan dapat secara maksimal dapat dirasakan oleh masyarakat. Hal ini sesuai dengan pendapat Wibisono Yusuf yang menyatakan sentralisasi berarti program aplikasi tanggung jawab sosial terpusat di perusahaan. Perusahaan yang merencanakan, dan menentukan program, merumuskan strategi perusahaan dan sekaligus sebagai yang melaksanakan program yang direncanakan. ${ }^{22}$

Program CSR Bank Muamalat Cabang Makassar dinilai tepat jika program CSR dimaknai sebagai kehendak dan tindakan sadar yang berorientasi pada nilai-nilai tertentu (value oriented action) yang merujuk pada keutamaan moral, etika, atau keinginan untuk memberi yang terbaik, atau suatu sikap voluntaristik

\footnotetext{
${ }^{21}$ Laporan Tahunan, Annual Report 2015 PT. Bank Muamalat Indonesia

22 Yusuf Wibisono, Membedah Konsep Aplikasi Corporate Social Responsibility, (Fascho Publishing, Gresik, 2007), h. 33
} 
dengan orientasi maksimalis. Berbesar hati, berlapang dada untuk melakukan sesuatu melampaui kewajiban yang ditetapkan (beyond compliance). Di sinilah sesungguhnya spirit realisasi CSR secara substansial. CSR lebih dari sekadar filantropi. Konsep itu juga lebih dari sekadar pengungkapan empati sosial. Pelaksanaan CSR mempersyaratkan kesadaran penuh bahwa setiap kegiatan pemanfaatan/pengubahan sumberdaya (alam) termasuk energi menjadi output tertentu dalam rangka bisnis selalu berada dalam interaksi konstan dan terus menerus dengan lingkungan sosial dan fisik di sekitarnya.

Kesadaran ini juga menjelaskan bahwa seluruh proses kegiatan bisnis, atau apapun dalam derajat yang bervariasi sesuai skala kegiatannya akan selalu berdampak baik positif maupun negatif. Karena itulah wujud output kebijakan/ program CSR harus berkait dengan upaya memaksimumkan dampak positif dan meminimalkan dampak negatif dari suatu kegiatan (bisnis) tertentu.

Dengan dasar pemaknaan realisasi CSR seperti di atas, maka sudah seharusnya seluruh program CSR yang akan direalisasi oleh suatu institusi perbankan syariah, harus memiliki dasar alasan dalam menentukan program yang akan ditetapkan sebagai program CSR. Dasar alasan inilah yang menjadi pokok pertimbangan untuk mengambil keputusan tentang bentuk programprogram CSR yang akan direalisasikan. Pokok pertimbangan ini juga dapat digunakan sebagai indikator tepat atau tidaknya suatu program dilihat dari kacamata praksis CSR secara substansial.

Jika realisasi program CSR Bank Muamalat Cabang Makassar telah direncanakan dengan sadar dan dilaksanakan dalam koridor meminimumkan dampak negatif dan memaksimumkan dampak positif dari inti kegiatan (core business) perbankan maka layaklah itu disebut program CSR perbankan yang tepat. Menurut Busyra Azheri, tanggung jawab moral (responsibility) adalah 
perasaan bertanggung jawab yang bersumber dari budi pekerti, sikap mental atau budi perangai yang tergambar dalam bentuk tingkah laku dan sebagainya yang merupakan ekspresi jiwa, yang akan melahirkan perbuatan baik menurut akal dan syari'at. 23

Ada empat manfaat yang diperoleh bagi perusahaan dengan mengimplementasikan CSR. Pertama, keberadaan perusahaan dapat tumbuh dan berkelanjutan dan perusahaan mendapatkan citra yang positif dari masyarakat luas. Kedua, perusahaan lebih mudah memperoleh akses terhadap modal (capital). Ketiga, perusahaan dapat mempertahankan sumber daya manusia (human resources) yang berkualitas. Keempat, perusahaan dapat meningkatkan pengambilan keputusan pada hal-hal yang kritis (critical decision making) dan mempermudah pengelolaan manajemen risiko (risk management). ${ }^{24}$

\section{Penutup}

Tanggungjawa sosial yang diimplementasikan sesuai dengan perspektif ekonomi Islam, yang mengedepankan nilai-nilai ibadah. Kegiatan tanggungjawab sosial Bank Muamalat sesuai dengan visi dan misi Bank Muamalat yang dijadikan sebagai acuan dalam melaksanakan kegiatan, sehingga dapat dikatakan bahwa CSR yang dilaksanakan sudah sesuai dengan konsep syariah. Hal ini terbukti dengan adanya kegiatan CSR dan juga dengan berjalannya program-program yang berhubungan dengan sosial kemasyarakatan sehingga

${ }^{23}$ Azheri, Busyra. Corporate Social Responsibility dari Voluntary menjadi Mandatory. (Jakarta: Rajawali Pers. 2012), h. 112

${ }^{24}$ Muhammad Arief Effendi, "Implementasi GCG Melalui CSR", 7 November 2007, diakses dari muhariefeffendi.wordpress.com 
dapat mengurangi sedikit beban ekonomi masyarakat dengan memberikan santunan sosial keagamaan. Sesuai dengan misi yang ke empat yaitu menciptakan wahana terbaik sebagai tempat kebanggaan untuk berkarya dan berprestasi bagi pegawai sebagai perwujudan ibadah.

\section{Daftar Pustaka}

Al-Quran dan Terjemahan.

Al-Faruqi, Isma'il Raji, Islamization of Knowledge: General Principles and Workplan, diterjemahkan Anas Mahyudin, Cet. 1, (Bandung: Pustaka, 1984)

Ali, Zainuddin, Metode Penelitian Hukum (Jakarta: Sinar Grafika, 2011)

Azwar, Saifudin, Metode Penelitian (Cet. Ke-2; Yogyakarta: Pustaka Pelajar, 2000),

Agustin, RR Triani, Analisis Hubungan Antara Kinerja Ekonomi dan Kinerja Lingkungan dengan Alokasi Dana CSR Pada Perusahaan Ekstraktif,

Antonio, Muhammad Syafi'i, Bank Syariah dari Teori ke Praktik, (Jakarta: Gema Insani Press, 2001)

Beekun, Rafik Issa, Etika Bisnis Islami, (Yogyakarta: Pustaka Pelajar, 2004)

Busyra. Azheri, Corporate Social Responsibility dari Voluntary menjadi Mandatory. (Jakarta: Rajawali Pers. 2012)

Chapra, Umer, Sistem Moneter Islam, (Jakarta : Gema Insani Press, 2000)

Effendi, Muhammad Arief, "Implementasi GCG Melalui CSR", 7 November 2007, diakses dari muhariefeffendi.wordpress.com

Farrok, Syad, On Corporate Social Responsibility of Islamic Financial Instittusions. Islamic Economic Studies 15, no. 1, July 2007

Hasyir, Dede Abdul, Praktek Corporate Social Responsibility Yang Terintegrasi Dan Contoh Implementasinya Pada Industri Perbankan, Working Paper Research Days, Faculty of Economics - Padjadjaran University, Bandung Oktober 2009 
Hadikusuma, Hilmah, Metode Pembuatan Kertas Kerja Atau Skripsi Ilmu Hukum (Bandung: Alfabeta, 1995)

Hafida, Andi Safitri. Implementasi Shariah Enterprise Theory Melalui Value Added Statement Untuk Menilai Tanggung Jawab Perbankan Syariah Kepada Stakeholders. Skripsi. Makassar : Fakultas Ekonomi dan Bisnis Universitas Hasanuddin, 2012

Iwan Triyonwono, Sinergi Oposisi Biner: Formulasi Tujuan Dasar Laporan Keuangan Syariah. IQTISAD Journal of Islamic Economics 4, No. 1. Maret 2003

Khairunnisa, "Analisa Perbandingan Rasio Keuangan Bank Syariah Sebelum dan Sesudah Menerapkan Corporaste Social Responsibility (CSR) (Studi Pada PT. Bank Muamalat Tbk.)", Skripsi (Jakarta : Fakultas Syariah dan Hukum UIN Syarif Hidayatullah, 2010)

Justice, Dwight W. Corporate Social Responsibility: Challenges and Opportunity for Trade Unionsts, in Labour Education No. 130 ILO Bureau for Workers Activities, International Labour Office, Geneva, 2003.

Marzuki, Metodologi Riset, (BPFE-UII, Yogyakarta, 2002)

Moloeng, Lexy, J. Metodologi Penelitian Kualitatif, (Bandung: Rosdakarya, 1993)

Muid, Dul, "Pengaruh Corporate Social Reponsibility Terhadap Stock Return", Fokus Ekonomi, (2011)

Nawawi, M. Kholik, dan Fera Astarini, Peran Penyaluran Dana Corporate Social Responsibility (CSR) Dalam Meningkatkan Kepercayaan Nasabah Studi Kasus Di P.T. Bank Mandiri Syariah Cabang Bogor, Jurnal Ekonomi Islam Al-Infaq 1, no. 1, September 2010

Noor, Juliansyah, Metodologi Penelitian : Skripsi, Tesis, Disertasi dan Karya Ilmiah,

Sugiyono, Metode Penelitian Kuantitatif, Kualitatif, dan R\&D (Bandung: Alfabeta, 2016)

Setiadi, Nugroho J. Perilaku Konsumen (Jakarta: Prenadamedia Group,2015)

Subagyo, Joko, Metode Penelitian (Dalam Teori Praktek) (Jakarta, Rineka Cipta: 2006)

Sembiring, Edi Rismanda, Faktor-Faktor yang Mempengaruhi Pengungkapan Tanggung Jawab Sosial Perusahaan. Jurnal Telaah Akuntansi 01 No. 01 Juni 2003 
Rivai, Veithzal dkk., Bank and Financial Institution Management, (Jakarta : RajaGrafindo Persada, 2007)

Retno, Reni Dyah, dan Denies Praiantinah. Pengaruh Good Corporate Governance dan Pengungkapan Corporate Social Responsibility Terhadap Nilai Perusahaan (Studi Empiris Pada Perusahaan Yang Terdaftar di Bursa Efek Indonesia Periode 2007-2010). Jurnal Nominal 1, No.1 2012

Rusdi, M. A. (2017). Maslahat Sebagai Metode Ijtihad Dan Tujuan Utama Hukum Islam. DIKTUM: Jurnal Syariah dan Hukum, 15(2), 151-168.

Wibisono, Yusuf, Membedah Konsep Aplikasi Corporate Social Responsibility, (Fascho Publishing, Gresik, 2007)

Yacoob, AA., Islamic Banking and Economic Development, Dissertation, (Univeristy of Maryland, 1986)

\section{Artikel Internet}

http/www.csrIndonesia.com

http/www.bi.go.id.

Laporan Pelaksanaan Tata Kelola Perusahaan Tahun 2015 Bank Muamalat Indonesia

Laporan Tahunan, Annual Report 2015 PT. Bank Muamalat Indonesia

\section{Peraturan-Peraturan}

Fatwa Dewan Syariah Nasional No.04/DSN-MUI/IV/2000.

Indonesia Undang-Undang Republik Indonesia tentang Perseroan Terbatas Nomor Tahun 2007.

Indonesia, Undang-Undang Republik Indonesia Nomor 10 Tahun 1998 tentang Perubahan atas Undang-Undang Nomor 7 Tahun 1992 tentang Perbankan.

Undang-Undang Tentang Penanaman Modal. Undang-Undang Nomor 25 Tahun 2007. LNRI Tahun 2007 No. 67. TLNRI No. 4724.

Undang-Undang tentang Perbankan Syariah. Nomor 21 tahun 2008. 
Peraturan Bank Indonesia No.6/24/PBI/2004 tentang Bank Umum Yang Melaksanakan Usaha Berdasarkan Syariah. 